\title{
The biochemical content and antioxidant capacities of endemic Tanacetum densum (Lab.) Schultz Bip. subsp. laxum, and Tanacetum densum (Lab.) Schultz Bip. subsp. amani Heywood growing in Turkey
}

\author{
I. Emre ${ }^{a *}$ \\ aFirat University, Faculty of Education, Department of Basic Education, Elazig, Turkey \\ *e-mail: irfanemre1@yahoo.com
}

Received: June 2, 2020 - Accepted: September 10, 2020

\begin{abstract}
Medicinal plants have a significant role in preventing and curing several diseases, and Tanacetum L. is one of these plants. The aim of the present study is to determine the fatty acid, lipid-soluble vitamin, sterol, phenolic content, and antioxidant capacity of Tanacetum densum subsp. laxum and Tanacetum densum subsp. amani, to compare the effect of altitude on the biochemical content and to compare systematically by using fatty acids and phenolics. This study showed that palmitic acid (C16:0) and stearic acid (C18:0) are major sources of saturated fatty acid and oleic acid (C18:1 n9), and linoleic acid (18:2 n6c) and a-linolenic acid (C18:3 n3) are the principal unsaturated fatty acids in the two endemic Tanacetum densum taxa. Also, this study found that the unsaturated fatty acid content $(60.11 \pm 1.61 \%)$ of Tanacetum densum subsp. laxum was higher than the unsaturated fatty acid content $(44.13 \pm 1.28 \%)$ of Tanacetum densum subsp. amani. And also, the $\omega 6 / \omega 3$ ratio of Tanacetum densum subsp. laxum (1.74) and Tanacetum densum subsp. amani (1.60) was found to be similar. However, this study determined that the lipid soluble vitamin and sterol content of two endemic Tanacetum taxa are low except for stigmasterol. Present study showed that catechin is principal phenolic in the Tanacetum densum taxa. This study also found that Tanacetum densum subsp. laxum and Tanacetum densum subsp. amani had the highest levels of catechin, vanillic acid, and caffeic acid content though the phenolic amounts, particularly catechin and quercetin, were dissimilar in the T. densum taxa. This study suggested that ecological conditions such as altitude may affect the biochemical content of two endemic Tanacetum densum taxa. Furthermore, the current study determined that two endemic Tanacetum L. taxa had potent radical scavenging capacities and found a correlation between total phenolics and antioxidant activity.
\end{abstract}

Keywords: antioxidant capacity, fatty acids, lipid soluble vitamins, sterols, Tanacetum densum.

\section{O conteúdo bioquímico e as capacidades antioxidantes de Tanacetum densum endêmico (lab.) Schultz Bip. subsp. laxum e Tanacetum densum (lab.) Schultz Bip. subsp. amani Heywood que crescem na Turquia}

\begin{abstract}
Resumo
As plantas medicinais têm um papel significativo na prevenção e cura de várias doenças, e Tanacetum L. é uma dessas plantas. O objetivo do presente estudo é determinar o conteúdo de ácido graxo, vitamina lipossolúvel, esterol, estrutura fenólica e capacidade antioxidante de Tanacetum densum subsp. laxum e Tanacetum densum subsp. amani, comparar o efeito da altitude sobre o conteúdo bioquímico e realizar uma comparação sistemática usando ácidos graxos e fenólicos. Esta pesquisa mostrou que o ácido palmítico (C16:0) e o ácido esteárico (C18:0) são as principais fontes de ácido graxo saturado e que o ácido oleico (C18:1 n9), o ácido linoleico (18:2 n6c) e o ácido a-linolênico (C18: 3 n3) são os principais ácidos graxos insaturados nos dois táxons endêmicos de Tanacetum densum. Além disso, este estudo descobriu que o conteúdo de ácidos graxos insaturados $(60,11 \pm 1,61 \%)$ de Tanacetum densum subsp. laxum foi superior ao conteúdo de ácidos graxos insaturados $(44,13 \pm 1,28 \%)$ de Tanacetum densum subsp. amani, e também que a razão $\omega 6 / \omega 3$ de Tanacetum densum subsp. laxum $(1,74)$ e Tanacetum densum subsp. amani $(1,60)$ foi semelhante. No entanto, este trabalho determinou que o conteúdo de vitamina lipossolúvel e esterol de dois táxons endêmicos de Tanacetum é baixo, exceto o estigmasterol, além de descobrir que Tanacetum densum subsp. laxum e Tanacetum densum subsp. amani apresentaram os mais altos níveis de conteúdo de catequina, ácido vanílico e ácido cafeico, embora as quantidades fenólicas, especialmente catequina e quercetina, sejam diferentes nos táxons de $T$. densum. Este estudo sugere que condições ecológicas, como a altitude, podem afetar o conteúdo bioquímico de dois táxons endêmicos de Tanacetum densum. Ainda, esta pesquisa determinou que dois táxons de Tanacetum L. endêmicos possuíam potentes capacidades de sequestro de radicais e que houve correlação entre fenólicos totais e atividade antioxidante.
\end{abstract}

Palavras-chave: capacidade antioxidante, ácidos graxos, vitaminas lipossolúveis, esteróis, Tanacetum densum. 


\section{Introduction}

The Asteraceae family includes about 23.000 species throughout the world, and Tanacetum L. is the third biggest genus in the family (Yur et al., 2017). Tanacetum L. is found extensively in the northern hemisphere, especially in Europe, western Asia, North America, and north Africa include approximately 200 species (Oberprieler et al., 2007; Baranauskienè et al., 2014; Korkmaz et al., 2015; Baczek et al., 2017). The members of the genus generally are perennial and vary from herbs to subshrubs (Oberprieler et al., 2007).

Tanacetum L. has significant biological effects including antimicrobial, antioxidant, anti-inflammatory, and anticancer, and the genus has been used in folk medicine since ancient times for the treatment of migraine, stomach ache, toothache, insect bites, cancer, ulcers, high fever, arthritis, and vertigo (Marete et al., 2009; Marzouk et al., 2016; Mot et al., 2018; Coban et al., 2019). Additionally, Tanacetum, which is grown in gardens, is used in cosmetics and as a spicy food additive (Maxia et al., 2015; Mot et al., 2018). It has been demonstrated that essential oils, sterols, flavonoids, and sesquiterpenes are commonly found in this genus (Kilic, 2014; Marzouk et al., 2016). The genus is represented in Turkey by sixty taxa, and the endemism ratio is $43 \%$ (Orhan et al., 2015). T. densum, one of the endemic species, has four subspecies growing in Turkey: subsp. sivasicum, subsp. laxum, subsp. amani and subsp. eginense (Goren et al., 1995). Tanacetum densum is perennial, endemic, erect, or ascending subshrubs, the habitat is the limestone rocks and screes (1500-2500), and flowering time period is between June and August (Davis, 1988). The aim of the present study was to analyze the fatty acids, lipid-soluble vitamins, sterols, total phenolics, flavonoids, and phenolic acids as well as the radical scavenging and FRAP activities of plant extracts of endemic T. densum subsp. laxum and T. densum subsp. amani in order to contribute to knowledge of the medicinal properties of two Tanacetum taxa. Another aim of this study was to examine the effect of altitude on fatty acid and phenolic content and to systematically evaluate the fatty acid composition and phenolic content.

\section{Material and Methods}

All chemicals were purchased from Sigma-Aldrich. The plant materials were collected from natural habitats in 2014 July, and samples were stored at the Firat University
Herbarium (FUH). The localities of the two taxa under examination are given Table 1.

\subsection{Extraction of plant materials}

\subsubsection{Analysis for fatty acids, lipid soluble vitamins,} and sterols

Two g of plant materials was ground in a mill, and isopropanol/hexane $(2: 3 \mathrm{v} / \mathrm{v})$ was added to analyze fatty acid, sterol, and lipid soluble vitamins (Hara \& Radin, 1978). The lipid extract was centrifuged at $10.000 \mathrm{~g}$ for five minutes and filtered. The solvent was then removed by using a rotary evaporator at $40^{\circ} \mathrm{C}$. The samples were left at $-25^{\circ} \mathrm{C}$.

\subsubsection{Analysis for fatty acids}

To obtain the fatty acid methyl esters, $2 \%$ sulphuric $\operatorname{acid}(\mathrm{v} / \mathrm{v})$ in methanol was used (Christie, 1990). N-hexane was added to the fatty acid methyl esters and isolated by gas chromatography and flame-ionization detection (Shimadzu GC 17 Ver.3) coupled with a Glass GC 10 software. Nitrogen was used as a carrier gas with a flow ratio of $0.8 \mathrm{ml} / \mathrm{min}$. and a capillary column of $25 \mathrm{~m}$ in length and $0.25 \mathrm{~mm}$ in diameter; Permabound 25 (Macherey-Nagel, Germany) was used to conduct the chromatographic separation.

\subsubsection{Chromatographic analysis and quantification of lipid-soluble vitamins and sterols.}

Lipid-soluble vitamins and phytosterols were obtained from the lipid fraction based on the method of Sánchez-Machado et al. (2002). The samples were suspended in acetonitrile/methanol $(75 / 25 \mathrm{v} / \mathrm{v})$, and $50 \mathrm{~mL}$ was added to the HPLC (Shimadzu, Japan). A Supelcosil TM LC18 ( $250 \times 4.6 \mathrm{~mm}, 5 \mathrm{~mm}$, Sigma, USA) was used as column and acetonitrile/methanol $(75 / 25, \mathrm{v} / \mathrm{v})$ for the mobile phase. The temperature of the column was kept at $40^{\circ} \mathrm{C}$. The wavelength was $320 \mathrm{~nm}$ for retinol (vitamin A) and retinol acetate; $215 \mathrm{~nm}$ for d-tocopherol, vitamin D, a-tocopherol, and a-tocopherol acetate; $202 \mathrm{~nm}$ for phytosterols; and $265 \mathrm{~nm}$ for vitamin K1 (López-Cervantes et al., 2006). The results of the analyses were measured as $\mu \mathrm{g} / \mathrm{g}$.

\subsection{Extraction of plant material for phenolics}

Five $\mathrm{ml} 80 \%$ methanol was used to homogenize the flavonoid and phenolic acids. The extracts were centrifuged at $5000 \mathrm{rpm}$ at $+4^{\circ} \mathrm{C}$, and dimethyl sulfoxide (DMSO) was used to provide a reserve solution (Kursat et al., 2011).

Table 1. The localities of Tanacetum densum subsp. amani and Tanacetum densum subsp. laxum

\begin{tabular}{|c|c|c|c|}
\hline Taxa & Locality & Coordinates & Herbarium number \\
\hline $\begin{array}{l}\text { Tanacetum densum (Lab.) } \\
\text { Schultz Bip subsp. laxum }\end{array}$ & $\begin{array}{c}\text { Elazig, Baskil, Bolucuk } \\
\text { village, Hasan mountain, } \\
1600 \mathrm{~m} .\end{array}$ & $38^{\circ} .59^{\prime} 36402^{\prime \prime} \mathrm{N}, 38^{\circ} .86^{\prime} 46655^{\prime \prime} \mathrm{E}$ & FUH 10101 \\
\hline $\begin{array}{l}\text { Tanacetum densum (Lab.) } \\
\text { Schultz Bip subsp. amani } \\
\text { Heywood }\end{array}$ & $\begin{array}{c}\text { Elazig, Baskil, Bolucuk } \\
\text { village, Hasan mountain, } \\
\text { 1800-1900 m. }\end{array}$ & $38^{\circ} .59^{\prime} 45642^{\prime \prime} \mathrm{N}, 38^{\circ} .86^{\prime} 49200^{\prime \prime} \mathrm{E}$ & FUH10102 \\
\hline
\end{tabular}




\subsubsection{Determination of total phenolics}

Total phenolics were evaluated using the Folin-Ciocalteu method (Singleton et al., 1999). $100 \mu \mathrm{l}$ of the extracts was added to the mixture that included $200 \mu 1$ of Folin-Ciocalteu reagent and $3.16 \mathrm{ml}$ of $\mathrm{H}_{2} \mathrm{O}$. The samples were kept at room temperature for three min. The extracts were left at room temperature for two hours after anhydrous sodium carbonate $(20 \% ; \mathrm{w} / \mathrm{v})$ was added to the mixture. The absorbance of the samples was analyzed at $765 \mathrm{~nm}$ (Sarhan et al., 2013).

\subsubsection{Chromatographic conditions of the flavonoids}

Chromatographic analysis was performed by $\mathrm{Zu}$ et al. (2006). The column was a PREVAIL C18 reversed-phase column $(15 \times 4.6 \mathrm{~mm}, 5 \mu \mathrm{m}$, USA), and the mobile phase was methanol/water/acetonitrile (46/46/8, v/v/v) including $1.0 \%$ acetic acid ( $\mathrm{Zu}$ et al., 2006). The chromatographic peaks were confirmed by determining retention times with those of the standards. Resveratrol, quercetin, naringenin, naringin, catechin, myricetin, morin, rutin, kaempferol and vanillic acid, cinnamic acid, caffeic acid, and rosmarinic acid were analyzed by DAD following RP-HPLC. The flow ratio was $1.0 \mathrm{ml} / \mathrm{min}$, and the chromatographic studies were performed at $25^{\circ} \mathrm{C}$.

\subsection{Antioxidant activity}

\subsubsection{DPPH radical scavenging capacity}

The DPPH radical was prepared afresh based on the method by Liyana-Pathirana \& Shahidi (2005). A 4. $0 \mathrm{ml}$ DPPH solution was added to $25,50,100,150$, and $250 \mu \mathrm{L}$ of the extract. The complex was kept in the dark for 30 minutes. The absorbance at a wavelength of $517 \mathrm{~nm}$ was measured spectrophotometrically. $1 \mu \mathrm{M}$ quercetin was used as a reference (Liyana-Pathirana \& Shahidi, 2005). The results were measured by using the following formula: DPPH radical scavenging activity $(\%)=[($ Abs_control-Abs_sample $)] /($ Abs control $)] \times 100$. The abs control is the absorbance of DPPH radical + methanol; the Abs_sample is the absorbance of DPPH radical + sample extract/standard.

\subsubsection{ABTS 2.2-azinobis-(3-ethylbenzothiazoline-6- sulfonic acid) diammonium salt assay}

The ABTS radical cation assay was measured based on the method of Re et al. (1999). To obtain ABTS radical cation, the ABTS radical cation $\left(\mathrm{ABTS}^{++}\right.$) and $7 \mathrm{mMABTS}$ were added to $2.45 \mathrm{mM}$ potassium persulfate. The solution was kept for $12-16 \mathrm{~h}$ at room temperature. The (ABTS $\left.\bullet^{+}\right)$ solution was dissolved in water to measure an absorbance of $0.700 \pm 0.020$ at $734 \mathrm{~nm} .3 \mathrm{ml}$ ABTS solution was added to $25,50,100,150$, and $250 \mu \mathrm{L}$ of samples, and absorption was measured over six min. Absorbance of the control $\left(3.0 \mathrm{~mL}\left(\mathrm{ABTS}^{\bullet+}\right)\right.$ solution with $30 \mathrm{~L}$ water) was written as A control. (Skotti et al., 2014). The ABTS radical cation scavenging capacity (\%) equals [(Abs_control Abs_sample)]/ (Abs_control)] x 100.

\subsubsection{Ferric-reducing antioxidant power assay (FRAP)}

The FRAP method was performed using the procedure of Benzie \& Strain (1996). A sodium acetate buffer $(300 \mathrm{mmol} / \mathrm{l})$, a TPTZ solution in $40 \mathrm{mmol} / \mathrm{l}$, and $20 \mathrm{mmol} / 1 \mathrm{FeCl}_{3}(10: 1: 1 ; \mathrm{v} / \mathrm{v})$ were used to prepare the FRAP reagent. The absorbance was measured at $593 \mathrm{~nm}$ after $10 \mathrm{~min}$. The $\mathrm{FeSO}_{4}$ solution $(100-2000 \mathrm{mmol} / \mathrm{L})$ was used to form the standard curve. The results were evaluated as $\mathrm{mM} \mathrm{Fe}(\mathrm{II}) / \mathrm{g}$.

\subsection{Statistical analysis}

All analyses were done using the SPSS 21.0 statistical program. The simple linear regression model was used to determine the correlation between antioxidant capacity (ABTS and DPPH) and total phenolic contents. Data taken from the present study was represented as mean values \pm standard deviation.

\section{Results and Discussion}

Tanacetum L. have been used since ancient times as medicinal plants, but to understand their curative effect, comprehensive phytochemical and pharmacological studies are required (Ivanescu et al., 2018). It was found that $T$. densum subsp. amani $(55.84 \pm 1.31 \%)$ had a higher saturated fatty acid content than T. densum subsp. laxum $(44.13 \pm 1.28 \%)$. Palmitic acid (C16:0) was the major saturated fatty acid while linoleic acid (C18:2 n6) was the major unsaturated fatty acid in two endemic subspecies (Table 2). Also, stearic acid (C18:0) was the second highest saturated fatty acid, and arachidic acid (C20:0) was the third highest saturated fatty acid in $T$. densum subsp. laxum. In addition, arachidic acid and stearic acid were found to be the saturated fatty acids in $T$. densum subsp. amani. The other saturated fatty acids in T. densum subsp. laxum were capric acid (C10:0) and myristic acid (C14:0). Demirpolat et al. (2019) determined that palmitic acid (C16:0) and stearic acid (C18:0) were the major saturated fatty acids in T. densum subsp. eginense. On the other hand, Rezaei et al. (2017) determined that T. parthenium had mainly palmitic acid $(57.27 \%)$ and myristic acid (14.7\%), saturated fatty acids. Oleic acid (C18:1 n9), linoleic acid (18:2 n6c), and a-linolenic acid (C18:3 n3) were the unsaturated fatty acids in the present study (Table 2). It was shown that the total unsaturated fatty acid compositions of $T$. densum subsp. laxum was $60.1 \pm 1.61 \%$ whilst the total unsaturated fatty acid compositions of $T$. densum subsp. subsp. amani was $44.13 \pm 1.28 \%$. The health effect of dietary fats from the plants are based on the polyunsaturated and monounsaturated fatty acid composition (Ayaz et al., 2017). In addition, the $\omega 3$ (alpha linolenic acid 18:2) and the $\omega 6$ (cis linoleic acid; 18:2) fatty acids are essential fatty acids (called vitamin F), and they cannot be synthesized by humans and must be taken in food (Konukoglu, 2008; Kam\&Saydan Kanberoglu, 2019). This study showed that $T$. densum subsp. laxum has a higher linoleic acid (C18:2 n6; 28.31 $2.61 \%)$ and 
Table 2. Fatty acid compositions \% of Tanacetum taxa.

\begin{tabular}{ccc}
\hline Fatty Acids (\%) & Tanacetum densum subsp. laxum & Tancetum densum subsp. amani \\
\hline $10: 0$ & $2.09 \pm 0.54$ & - \\
$14: 0$ & $2.55 \pm 0.78$ & - \\
$16: 0$ & $24.54 \pm 1.37$ & $37.49 \pm 2.34$ \\
$18: 0$ & $5.72 \pm 0.97$ & $9.47 \pm 0.89$ \\
$20: 0$ & $4.94 \pm 0.85$ & $8.88 \pm 1.1$ \\
¿Saturated fatty acids & $39.84 \pm 1.37$ & $55.84 \pm 1.31$ \\
$18: 1$ n9 & $11.75 \pm 1.13$ & $11.37 \pm 1.01$ \\
$18: 2$ n6c & $28.31 \pm 2.61$ & $17.02 \pm 1.58$ \\
$18: 3 n 3$ & $16.22 \pm 1.1$ & $10.59 \pm 1.26$ \\
$20: 4 n 6$ & $3.83 \pm 0.76$ & $5.15 \pm 0.93$ \\
\hline
\end{tabular}

Table 3. Lipid soluble vitamin and sterol contents of Tanacetum taxa $(\mu \mathrm{g} / \mathrm{g})$.

\begin{tabular}{ccc}
\hline Lipid-soluble vitamins $(\boldsymbol{\mu g} / \mathbf{g})$ & Tanacetum densum subsp. laxum & Tancetum densum subsp. amani \\
\hline K1 & $1.5 \pm 0.22$ & $0.75 \pm 0.19$ \\
K2 & - & - \\
R-tocopherol & $0.55 \pm 0.1$ & $0.8 \pm 0.14$ \\
D2 & $0.05 \pm 0.01$ & $0.05 \pm 0.01$ \\
D3 & $0.1 \pm 0.01$ & $0.2 \pm 0.01$ \\
a-tocopherol & $7.3 \pm 0.67$ & $5 \pm 0.57$ \\
Retinol & - & - \\
Retino acetate & $0.6 \pm 0.1$ & $0.65 \pm 0.26$ \\
Ergosterol & $0.75 \pm 0.1$ & $9.35 \pm 1.12$ \\
Stigmasterol & $59.45 \pm 3.11$ & $63.55 \pm 3.21$ \\
B-sitosterol & $0.7 \pm 0.1$ & $0.05 \pm 0.01$ \\
\hline
\end{tabular}

$\alpha$-linolenic acid (C18:3 n3; 16.22 $\pm 1.1 \%)$ content than the linoleic acid (C18:2 n6; 17.02 $\pm 1.58 \%)$ and $\alpha$-linolenic acid (C18:3 n3; 10.59 $\pm 1.26 \%$ ) content of $T$. densum subsp. amani. However, Demirpolat et al. (2019) indicated that linolenic acid (C18:3 n3) was a major unsaturated fatty acid in T. densum subsp. eginense. Oleic acid (C18:1 n9) was identified as a monounsaturated fatty acid the contents which of were similar in this study (Table 2). The differences in the major fatty acids in the T. densum taxa may be due to environmental conditions because the concentrations and compositions of oils are affected by environmental conditions (Seiler, 1994). Also, it has been reported that fatty acid composition is affected by the latitude of the growing field, and it was found that there is a negative correlation between latitude and linoleic acid (Turhan et al., 2010). Current results showed that there is a negative correlation between the linoleic acid (C18:2 n6) content and the latitude of two endemic Tanacetum taxa. Yur et al. (2017) indicated that T. haussknechtii (Bornm.) Grierson had palmitic acid (C16:0), linoleic acid (C18:2 n6), and linolenic acid (C18:3 n3) as major fatty acids while Eyol et al. (2017) found that Tanacetum zahlbruckneri had palmitic acid as the major saturated fatty acid $(21.28 \%-33.78 \%)$, and $\alpha$-linoleic acid (15.3\% and $18.09 \%)$ and $\alpha$-linolenic acid $(17.17 \%)$ were major unsaturated fatty acids. Besides, the fatty acid composition (especially of linoleic acid and linolenic acids) are significant biochemical tools for solving the taxonomical problems in the different systematic levels (Ayaz et al., 2017). This study demonstrated that the $\omega 6 / \omega 3$ ratio of $T$. densum subsp. laxum (1.74) and T. densum subsp. amani (1.60) was found to be similar.

The present study demonstrated that $T$. densum subsp. laxum and T. densum subsp. amani had the lowest lipid-soluble vitamins and ergosterol and $\beta$-sitosterol content (Table 3). However, the stigmasterol content of the two Tanacetum taxa studied was found to be between $59.45 \pm 3.11 \mu \mathrm{g} / \mathrm{mg}$ and $63.55 \pm 3.21 \mu \mathrm{g} / \mathrm{mg}$. Plant sterols are important elements that include the interaction between the free hydroxyl group protein and phospholipids and they protect the cells against cancer and cardiovascular diseases (Tosun et al., 2018; Beyzi et al., 2019). Furthermore, stigmasterol is an unsaturated plant sterol found in several medicinal plants and plays a significant role in the biosynthesis of androgens, estrogens, vitamin D3, and corticoids (Kaur et al., 2011). Azizudin \& Choudhary (2008) showed that $\beta$-sitosterol and stigmasterol were found in T. polycephalum. In another study, Ivanescu et al. (2018) showed that all three Tanacetum species (T. vulgare, T. macrophyllum, and T. corymbosum) contain beta-sitosterol, stigmasterol and campesterol, and traces of ergosterol. They found a high $\beta$-sitosterol content $(530.78 \mu \mathrm{g} / \mathrm{g} \mathrm{dw}-696.32 \mu \mathrm{g} / \mathrm{g} \mathrm{dw})$ compared to the present study (Ivanescu et al., 2018). 
Chandler et al. (1982) also found $\beta$-sitosterol to be the major sterol in Tanacetum. This research may be the first report regarding the lipid-soluble vitamin content of the two endemic Tanacetum taxa.

The studies demonstrated that phenolic content is responsible for the antioxidant activities of plants (Wojdylo et al., 2007; Arituluk et al., 2016). Phenolic content plays a preventive role against diabetes, cancer, cardiovascular disease, and Alzheimer's disease as well as in inducing DNA, cell adhesion, cell proliferation, and blocking signaling pathways (Huang et al., 2010; Gutierrez-Grijalva et al., 2016). Because synthetic antioxidants have harmful effects on health, there is a growing interest in natural antioxidants (Ahmed et al., 2011). This study found that the total phenolic contents of $T$. densum subsp. laxum and $T$. densum subsp. amani was $188.94 \pm 3.24 \mu \mathrm{g} / \mathrm{mg}$ and $137.01 \pm 2.47 \mu \mathrm{g} / \mathrm{mg}$, respectively (Table 4). Tepe\&Sokmen (2007) found that the total phenolic content of T. densum subsp. amani was $158.44 \pm 2.17 \mu \mathrm{g} / \mathrm{mg}$. However, Caniklioglu et al. (2018) determined that the total phenolic amount was $84.94 \pm 0.009 \mathrm{mg} / \mathrm{g}$ in the ethanol extracts of $T$. densum subsp. eginense. Also, catechin amounts were found at high levels in the present study $(1,299.4 \pm 7.52 \mu \mathrm{g} / \mathrm{mg}-5,796.9 \pm 8.12 \mu \mathrm{g} / \mathrm{mg})$. Though Michel et al. (2020) indicated that kaempherol glycosides are the main phenolic in the Asteracea, but present study showed that the major phenolic compound of $T$. densum taxa is catechin. Similarly, Gecibesler et al. (2016) found that catechin was a principal component of Tanacetum. The other phenolics studied were in low amounts or absent (Table 4). Zengin et al. (2019) indicated in their study that Tanacetum had various phenolics, but most of them were small amounts. On the other hand, the current study determined that $T$. densum subsp. laxum and T. densum subsp. amani had the highest vanillic acid $(1,543.7 \pm 6.12 \mu \mathrm{g} / \mathrm{mg}$ and $1070.3 \pm 4.91 \mu \mathrm{g} / \mathrm{mg}$, respectively) and caffeic acid $(1,234.9 \pm 5.64 \mu \mathrm{g} / \mathrm{mg}$ and $790 \pm 3.89 \mu \mathrm{g} / \mathrm{mg}$, respectively) contents (Table 5). Cinnamic acid was found trace amounts in the present study. It was also found that the rosmarinic acid amounts in T. densum taxa was the lowest (Table 5). Muresan et al. (2015) showed that Tanacetum had caffeic acid, ferulic acids, chlorogenic acid, rutin and quercetin, and kaempferol. They also showed that Tanacetum had good antioxidant activity (Muresan et al., 2015). Esmaeili et al. (2010) determined that the six Tanacetum species except for T. densum exhibited antioxidant activity. They also found that caffeic acid, ferulic acid, luteolin, apigenin, and rutin were major phenolic compounds in the Tanacetum species (Esmaeili et al., 2010). The differences in the phenolic amounts may originate from the growing conditions of the taxa because environmental factors including climate, weather, and sunlight exposure effect the phenolic content (Bahukhandi et al., 2013). Hashim et al. (2020) also indicated that ecological conditions affect antioxidant activity and the number of dominant constituents in endemic medical plants. In addition, it was reported that collection time has an important effect on the phenolic content (Varga et al., 2016). Climatic conditions, specifically the altitude of growing area, also effect the quantitative content of secondary metabolites such as phenolics at flowering time (Spitaler et al., 2008). The present results may suggest that the quantitative differences in the total phenolics, quercetin, catechin, caffeic acid, rosmarinic acid, and vanillic acid content of two endemic $T$. densum taxa exist because of the altitude. On the other hand, it has been suggested that qualitative and quantitative differences in the flavonoid and total phenolics could be used as taxonomical markers for tribes and subtribes of Asteraceae (Emerenciano et al., 2001; Sytar et al., 2018). In this study, while the phenolic content is similar in the two taxa studied, the phenolic amounts are different. The present study demonstrated that the two studied endemic taxa of $T$. densum had high DPPH (except for $25 \mu \mathrm{l}$ ) and ABTS radical scavenging activities (Tables 6,7). The present DPPH results agreed with the study by Yur et al. (2017) who indicated that the methanol extracts from Tanacetum represented the highest DPPH activity. Also, Zengin et al. (2019) showed that the water and methanol extracts from Tanacetum had high phenolic content and high ABTS and DPPH radical scavenging capacities. However, Caniklioglu et al. (2018) found that the DPPH $(20.64 \pm 0.26 \%-48.13 \pm 1.37 \%)$ and the ABTS radical scavenging activities $(12.65 \pm 0.23 \%$ and

Table 4. The results of total phenolics and flavonoid contents of Tanacetum taxa $(\mu \mathrm{g} / \mathrm{mg})$.

\begin{tabular}{|c|c|c|c|c|c|c|c|c|c|}
\hline Taxa & $\begin{array}{c}\text { Total } \\
\text { phenolics }\end{array}$ & Rutin & Myricetin & Quercetin & Kaempherol & Catechin & Naringin & Naringenin & Resveratrol \\
\hline $\begin{array}{c}\text { Tanacetum } \\
\text { densum subsp. } \\
\text { laxum }\end{array}$ & $188.94 \pm 3.24$ & $3.8 \pm 0.27$ & $0.7 \pm 0.01$ & $93.5 \pm 2.15$ & $18.7 \pm 0.94$ & $1,299.4 \pm 7.52$ & - & $8.5 \pm 0.64$ & $8.1 \pm 0.97$ \\
\hline $\begin{array}{c}\text { Tancetum } \\
\text { densum subsp. } \\
\text { amani }\end{array}$ & $137.01 \pm 2.47$ & $2.1 \pm 0.12$ & - & $33.21 \pm .13$ & $12.6 \pm 0.87$ & $5,796.9 \pm 8.12$ & - & $6.3 \pm 0.81$ & $5.2 \pm 0.43$ \\
\hline
\end{tabular}

Table 5. The results of phenolic acid contents of Tanacetum taxa $(\mu \mathrm{g} / \mathrm{mg})$.

\begin{tabular}{ccccc}
\hline Taxa & Vanillic acid & Cinnamic acid & Caffeic acid & Rosmarinic acid \\
\hline Tanacetum densum subsp. laxum & $1,543.7 \pm 6.12$ & $0.4 \pm 0.01$ & $1,234.9 \pm 5.64$ & $19.3 \pm 0.94$ \\
Tancetum densum subsp. amani & $1070.3 \pm 4.91$ & $0.2 \pm 0.01$ & $790 \pm 3.89$ & $2.3 \pm 0.4$ \\
\hline
\end{tabular}


Table 6. The DPPH \% results of Tanacetum taxa

\begin{tabular}{ccccccc}
\hline Taxa & $\mathbf{2 5} \boldsymbol{\mu l}$ & $\mathbf{5 0} \boldsymbol{\mu l}$ & $\mathbf{1 0 0} \boldsymbol{\mu l}$ & $\mathbf{1 5 0} \boldsymbol{\mu l}$ & $\mathbf{2 5 0} \boldsymbol{\mu l}$ & $\mathbf{5 0 0} \boldsymbol{\mu l}$ \\
\hline $\begin{array}{c}\text { Tanacetum densum } \\
\text { subsp. laxum }\end{array}$ & $16.07 \pm 1.11$ & $87.5 \pm 2.41$ & $89.28 \pm 2.34$ & $92.64 \pm 2.2$ & $94.8 \pm 1.96$ & $93.66 \pm 2.12$ \\
$\begin{array}{c}\text { Tancetum densum } \\
\text { subsp. amani }\end{array}$ & $16.94 \pm 0.97$ & $47.14 \pm 1.37$ & $68.83 \pm 2.71$ & $93.83 \pm 2.25$ & $94.9 \pm 1.74$ & $94.64 \pm 2.36$ \\
\hline
\end{tabular}

Table 7. The ABTS \% results and FRAP activities (mM Fe (II)/g) of Tanacetum taxa.

\begin{tabular}{cccccccc}
\hline Taxa & $\mathbf{2 5} \boldsymbol{\mu l}$ & $\mathbf{5 0} \boldsymbol{\mu l}$ & $\mathbf{1 0 0} \boldsymbol{\mu l}$ & $\mathbf{1 5 0} \boldsymbol{\mu l}$ & $\mathbf{2 5 0} \boldsymbol{\mu l}$ & $\mathbf{5 0 0} \boldsymbol{\mu l}$ & FRAP \\
\hline $\begin{array}{c}\text { Tanacetum densum } \\
\text { subsp. laxum }\end{array}$ & $76.68 \pm 2.14$ & $90.29 \pm 1.32$ & $83.76 \pm 2.72$ & $93.71 \pm 2.54$ & $98.6 \pm 1.76$ & $98.9 \pm 1.89$ & $566.97 \pm 4.57$ \\
$\begin{array}{c}\text { Tancetum densum } \\
\text { subsp. amani }\end{array}$ & $54.92 \pm 1.58$ & $54.01 \pm 1.12$ & $75.39 \pm 2.34$ & $95.46 \pm 2.17$ & $98.9 \pm 2.11$ & $98.95 \pm 1.63$ & $74.94 \pm 1.45$ \\
\hline
\end{tabular}

$23.58 \pm 0.49 \%$ ) in the ethanol extracts from $T$. densum subsp. eginense were lower than the present results. This study demonstrated that there is a strong correlation between total phenolics and $\operatorname{ABTS}\left(\mathrm{r}^{2}: .716\right)$ and a moderate correlation between total phenolics and DPPH $\left(\mathrm{r}^{2}: .274\right)$. Furthermore, this study showed that $T$. densum subsp. laxum had higher FRAP activity $(566.97 \pm 4.57 \mathrm{mM} \mathrm{Fe}$ (II)/g) than T. densum subsp. amani (74.94 $\pm 1.45 \mathrm{M} \mathrm{Fe}$ (II)/g, Table 7). Studies in the literature showed that Tanacetum had potent reducing power activity (Savci et al., 2019; Zengin et al., 2019).

\section{Conclusion}

This study found that palmitic acid (C16:0) and stearic acid (C18:0) were the major saturated fatty acids and oleic acid (C18:1 n9), linoleic acid (18:2 n6), and a-linolenic acid (C18:3 n3) were the dominant unsaturated fatty acids. Also, the present study showed that the polyunsaturated fatty acid composition of $T$. densum subsp. laxum was higher $(48.76 \pm 1.49 \%)$ than the poly unsaturated fatty acid composition ( $32.76 \pm 1.25 \%)$ of T. densum subsp. amani, but the mono unsaturated fatty acid compositions of $T$. densum taxa was similar. Besides, the $\omega 6 / \omega 3$ of $T$. densum subsp. laxum (1.74) and $T$. densum subsp. amani (1.60) was determined to be at a similar ratio. However, this study also determined that the lipid soluble vitamin and sterol content of two endemic Tanacetum taxa were low except for the stigmasterol contents of the studied Tanacetum taxa. Current study demonstrated that catechin is main phenolic compound in the two endemic $T$. densum taxa. It was shown in the present study that $T$. densum subsp. laxum and T. densum subsp. amani had the highest catechin, vanillic acid and caffeic acid contents but the phenolic amounts, particularly catechin and quercetin, were different in the T. densum taxa. This study proposed that altitude may affect the biochemical contents of two endemic Tanacetum densum taxa. Moreover, this study determined that two endemic Tanacetum taxa had strong DPPH and ABTS radical scavenging capacities, and T. densum subsp. laxum, in particular, had the highest FRAP activity. This study found that there was a correlation between total phenolics and antioxidant capacity.

\section{Acknowledgements}

I am grateful to Prof. Okkes Yilmaz and Assoc. Prof. Murat Kursat for assistance in analyse and identification of plants, respectively.

\section{References}

AHMED, J., GUVENC, A., KUÇUKBOYACI, N., BALDEMIR, A. and COSKUN, M., 2011. Total phenolic contents and antioxidant activities of Prangos Lindl. (Umbelliferae) species growing in Konya province (Turkey). Turkish Journal of Biology, vol. 35, pp. 353-360. http://dx.doi.org/10.3906/biy-0809-23.

ARITULUK, Z.C., TATLI CANKAYA, I.I. and GENCLER OZKAN, A.M., 2016. Antioxidant activity, total phenolic and flavonoid contents of some Tanacetum L. (Asteraceae) taxa growing in Turkey. Fabad Journal of Pharmaceutical Sciences, vol. 41 , no. 1 , pp. $17-25$.

AYAZ, F.A., OZCAN, M., KURT, A., KARAYIGIT, B., OZOGUL, Y., GLEW, R. and OZOGUL, F., 2017. Fatty acid composition and antioxidant capacity of cypselas in Centaureas.L. taxa (Asteraceae, Cardueae) from NE Anatolia. South African Journal of Botany, vol. 112, pp. 474-482. http://dx.doi.org/10.1016/j.sajb.2017.06.033.

AZIZUDIN, S. and CHOUDHARY, M.I., 2008. Compounds isolated from Tanacetum polycephalum. Turkish Journal of Chemistry, vol. 32, pp. 201-204.

BĄCZEK, K.B., KOSAKOWSKA, O., PRZYBYŁ, J.L., PIÓROJABRUCKA, E., COSTA, R., MONDELLO, L., GNIEWOSZ, M., SYNOWIEC, A. and WEGLARZ, Z., 2017. Antibacterial and antioxidant activity of essential oils and extracts from costmary (Tanacetum balsamita L.) and tansy (Tanacetum vulgare L.). Industrial Crops and Products, vol. 102, pp. 154-163. http:// dx.doi.org/10.1016/j.indcrop.2017.03.009.

BAHUKHANDI, A., RAWAT, S., BHATT, I.D. and RAWAL, R.S., 2013. Influence of solvent types and source of collection on total phenolic content and antioxidant activities of Acorus calamus L. National Academy Science Letters, vol. 36, no. 1, pp. 93-99. http://dx.doi.org/10.1007/s40009-012-0109-8.

BARANAUSKIENĖ, R., KAZERNAVIČIŪTĖ, R., PUKALSKIENĖ, M., MAŽDŽIERIENĖ, R. and VENSKUTONIS, P.R., 2014. Agrorefinery of Tanacetum vulgare L. into valuable products and evaluation of their antioxidant properties and phytochemical 
composition. Industrial Crops and Products, vol. 60, pp. 113-122. http://dx.doi.org/10.1016/j.indcrop.2014.05.047.

BENZIE, I.F. and STRAIN, J.J., 1996. The ferric reducing ability of plasma (FRAP) measure of "antioxidant power": the FRAP assay. Analytical Biochemistry, vol. 239, no. 1, pp. 70-76. http:// dx.doi.org/10.1006/abio.1996.0292. PMid:8660627.

BEYZI, E., BUYUKKILIC BEYZI, S., KARAMAN, K., 2019. Sterol profile of some medicinal and aromatic plant oils: effect of silyl derivatization process. European Journal of Science and Technology, no. 17, pp. 360-365. http://dx.doi.org/10.31590/ ejosat.597071

CANIKLIOGLU, A.G., TURKMEN, Z. and KANDEMIR, A., 2018. The determination of antioxidant activities of some endemic Tanacetum L. (Asteraceae) taxa growing in Erzincan and environment. Erzincan University Journal of Science and Technology, vol. 11, no. 2, pp. 207-222. http://dx.doi.org/10.18185/ erzifbed.372084.

CHANDLER, R.F., HOOPER, S.N., HOOPER, D.L., JAMIESON, W.D. and LEWIS, E., 1982. Herbal remedies of the Maritime Indians; sterols and triterpenes of Tanacetum vulgare L. Lipids, vol. 17, no. 2, pp. 102-106. http://dx.doi.org/10.1007/BF02535183. PMid:7087682.

CHRISTIE, W.W., 1990. Gas chromatography and lipids. Glaskow: The Oily Press.

COBAN, F., OZER, H. and METE, E., 2019. Essential oil composition of Tanacetum parthenium from the eastern black sea region, Turkey. ACS. Agriculturae Conspectus Scientificus, vol. 84 , no. 1, pp. 91-94.

DAVIS, P.H., 1988. Flora of Turkey and the East Aegean Islands. Edinburgh: Edinb. Un. Press, vol. 5, p. 261.

DEMIRPOLAT, A., KILIC, O., YILDIRIMLI, S. and BAGCI, E., 2019. Essential oil and fatty acid composition leaves of some aromatic plant taxa from Turkey. International Journal of Pharmacognosy and Pharmaceutical Research, vol. 2019, pp. 18-22.

EMERENCIANO, V.P., MILITÃO, J.S., CAMPOS, C.C., ROMOFF, P., KAPLAN, M.A., ZAMBON, M. and BRANT, A.J.. 2001. Flavonoids as chemotaxonomic markers for Asteraceae. Biochemical Systematics and Ecology, vol. 29, no. 9, pp. 947-957. http://dx.doi.org/10.1016/S0305-1978(01)00033-3. PMid:11445295.

ESMAEILI, M.A., SONBOLI, A. and AYYARI NOUSHABADI, M., 2010. Antioxidant and protective properties of six Tanacetum species against hydrogen peroxide-induced oxidative stress in K562 cell line: a comparative study. Food Chemistry, vol. 121, no. 1, pp. 148-155. http://dx.doi.org/10.1016/j.foodchem.2009.12.022.

EYOL, P.C., BOKE SARIKAHYA, N., KARAKOC, O.C., GOKCE, A., DEMIRCI, F., KIRMIZGUL, S. and GOREN, N., 2017. Fatty acid composition and biological activities of Tanacetum zahlbruckneri (Náb.) Grierson growing in Turkey. Records of Natural Products, vol. 11, no. 84, pp. 401-405.

GECIBESLER, I.H., KOCAK, A. and DEMIRTAS, I., 2016. Biological activities, phenolic profiles and essential oil components of Tanacetum cilicicum (Boiss.) Grierson. Natural Product Research, vol. 30, no. 24, pp. 2850-2855. http://dx.doi.org/10.1 080/14786419.2016.1163692. PMid:27059813.

GOREN, N., CAI, P., SCOTT, L., TIANOSOA-RAMOMONJY, M. and SNYDER, J.K., 1995. A new germacranolide from Tanacetum densum ssp sivasicum (COMPOSITAE). Tetrahedron, vol. 51, no. 16, pp. 4627-4634. http://dx.doi.org/10.1016/00404020(95)00164-4.
GUTIERREZ-GRIJALVA, E.P., AMBRIZ-PERE, D.L., LEYVALOPEZ, N., CASTILLO-LOPEZ, R.I. and HEREDIA, J.B., 2016. Review: dietary phenolic compounds, health benefits and bioacessibility. Alan, vol. 66, no. 2, pp. 1.

HARA, A. and RADIN, N.S., 1978. Lipid extraction of tissues with a low-toxicity solvent. Analytical Biochemistry, vol. 90, no. 1, pp. 420-426. http://dx.doi.org/10.1016/0003-2697(78)900465. PMid:727482

HASHIM, A.M., ALHARBI, B.M., ABDULMAJEED, A.W., ELKELISH, A., HOZZEIN, W.N. and HASSAN, H.B., 2020. Oxidative stress responses of some endemic plants to high altitudes by intensifying antioxidants and secondary metabolites content. Plants, vol. 9, no. 7, pp. 1-23. http://dx.doi.org/10.3390/ plants9070869. PMid:32659963.

HUANG, W.-Y., CAI, Y.-Z. and ZHANG, Y., 2010. Natural phenolic compounds from medicinal herbs and dietary plants: potential use for cancer prevention. Nutrition and Cancer, vol. 62, no. 1, pp. 1-20. http://dx.doi.org/10.1080/01635580903191585. PMid:20043255.

IVANESCU, B., TUCHILUS, C., CORCOIVA, A., LUNGU, C., MIHAI, C.T., GHELDIU, A.-M. and VLASE, L., 2018. Antioxidant, antimicrobial and cytotoxic activity of Tanacetum vulgare, Tanacetum corymbosum and Tanacetum macrophyllum extracts. Farmacia, vol. 66, no. 2, pp. 282-288.

KAM, N. and SAYDAN KANBEROGLU, G., 2019. Chemical analysis and fatty acid composition of the chicory plant (Cichorium intybus L.) by GC-MS. Journal of Engineering Technology and Applied Sciences, vol. 4, no. 2, pp. 51-62. http://dx.doi. org/10.30931/jetas.588102.

KAUR, N., CHAUDHARY, J., JAIN, A. and KISHORE, L., 2011. Stigmasterol: a comprehensive review. International Journal of Pharmaceutical Sciences and Research, vol. 2, no. 9, pp. 2259-2265.

KILIC, O., 2014. Essential oil composition of four endemic Tanacetum L. (Asteraceae) taxa from Turkey and a chemotaxonomic approach. Journal of Agricultural Science and Technology A, vol. 4, pp. 197-202.

KONUKOGLU, D., 2008. Properties, functions of omega-3 and omega- 6 fatty acids and relationship between essential fatty acids and cardiovasculer diseases. Türkiye Aile Hekimligi Dergisi, vol. 12, no. 3, pp. 121-129. http://dx.doi.org/10.2399/tahd.08.121.

KORKMAZ, M., KANDEMIR, A., ILHAN, V. and YILDIRIM DOGAN, N., 2015. Tanacetum erzincanense (Asteraceae), a new species from Erzincan, Turkey. Turkish Journal of Botany, vol. 39, pp. 96-104. http://dx.doi.org/10.3906/bot-1311-2.

KURŞAT, M., EMRE, İ., YILMAZ, Ö. and ERECEVIT, P., 2011. Antioxidant and antimicrobial activity in the seeds of Origanum vulgare L. subsp. gracile (C. Koch) Ietswaart and Origanum acutidens (Hand.-Mazz.) Ietswaart from Turkey. Grasas y Aceites, vol. 62, no. 4, pp. 410-417. http://dx.doi.org/10.3989/gya.113610.

LIYANA-PATHIRANA, C.M. and SHAHIDI, F., 2005. Antioxidant activity of commercial soft and hard wheat (Triticum aestivum L.) as affected by gastric $\mathrm{pH}$ conditions. Journal of Agricultural and Food Chemistry, vol. 53, no. 7, pp. 2433-2440. http://dx.doi. org/10.1021/jf049320i. PMid:15796575.

LÓPEZ-CERVANTES, J., SÁNCHEZ-MACHADO, D.I. and RÍOS-VÁZQUEZ, J., 2006. High-performance liquid chromatography method for the simultaneous quantification of retinol, $\alpha$-tocopherol, and cholesterol in shrimp waste hydrolysate. 
Journal of Chromatography A, vol. 1105, no. 1-2, 135-139. http:// dx.doi.org/10.1016/j.chroma.2005.08.010.

MARETE, E.N., JACQUIER, J.C. and O'RIORDAN, D., 2009. Effects of extraction temperature on the phenolic and parthenolide contents, and colour of aqueous feverfew (Tanacetum parthenium) extracts. Food Chemistry, vol. 117, no. 2, pp. 226-231. http:// dx.doi.org/10.1016/j.foodchem.2009.03.103.

MARZOUK, M.M., MOHAMED, T.A., ELKHATEEB, A., EL-TOUMY, S.A. and HEGAZY, M.E.F., 2016. Phenolics from Tanacetum sinaicum (Fresen.) Delile ex Bremer \& Humphries (Asteraceae). Biochemical Systematics and Ecology, vol. 65, pp. 143-146. http://dx.doi.org/10.1016/j.bse.2016.02.016.

MAXIA, A., SANNA, C., PIRAS, A., PORCEDDA, S., FALCONIERI, D., GONCALVES, M.J., CAVALEIRO, C. and SALGUEIRO, L., 2015. Chemical composition and biological activity of Tanacetum audibertii (Req.) DC. (Asteraceae), an endemic species of Sardinia Island, Italy. Industrial Crops and Products, vol. 65, pp. 472-476. http://dx.doi.org/10.1016/j. indcrop.2014.10.039.

MICHEL, J., ABD RANI, N.Z., HUSAIN, K., 2020. A review on the potential use of medicinal plants from Asteraceae and Lamiaceae plant family in cardiovascular diseases. Frontiers in Pharmacology, vol. 11, pp. 1-26. | https://doi.org/10.3389/ fphar.2020.00852.

MOT, C.A., LUPITU, A.I., BUNGAU, S., IOVAN, C., COPOLOVICI, D.M., PURZA, L., MELINTE (FRUNZULICA), C.E. and COPOLOVICI, L., 2018. Composition and antioxidant activity of aqueous extracts obtained from herb of Tansy (Tanacetum vulgare L.). Revista de Chimie, vol. 69, no. 5, pp. 1041-1044. http://dx.doi.org/10.37358/RC.18.5.6257.

MURESAN, M., BENEDEC, A., VLASE, L., OPREAN, R., TOIU, A. and ONIGA, I., 2015. Screening of polyphenolic compounds, antioxidant and antimicrobial properties of Tanacetum vulgare from Transylvania. Studia Universitatis Babes-Bolyai. Chemia, vol. 60 , no. 1 , pp. 127-138.

OBERPRIELER, C., HIMMELREICH, S. and VOGT, R., 2007. A new subtribal classification of the tribe Anthemideae (Compositae). Willdenowia, vol. 37, no. 1, pp. 89-114. http:// dx.doi.org/10.3372/wi.37.37104.

ORHAN, I.E., TOSUN, F., GULPINAR, A.R., KARTAL, M., DURAN, A., MIHOGLUGIL, F. and AKALGAN, D., 2015. LC-MS quantification of parthenolide and cholinesterase inhibitory potential of selected Tanacetum L. (Emend. Briq.) taxa. Phytochemistry Letters, vol. 11, pp. 347-352. http://dx.doi. org/10.1016/j.phytol.2014.10.003.

RE, R., PELLEGRINI, N., PROTEGGENTE, A., PANNALA, A., YANG, M. and RICE-EVANS, C., 1999. Antioxidant activity applying an improved ABTS radical cation decolorization assay. Free Radical Biology \& Medicine, vol. 26, no. 9-10, pp. 1231-1237. http://dx.doi.org/10.1016/S0891-5849(98)00315-3. PMid:10381194.

REZAEI, F., JAMEI, R. and HEIDARI, R., 2017. Evaluation of the phytochemical and antioxidant potential of aerial parts of Iranian Tanacetum parthenium. Pharmaceutical Sciences, vol. 23, no. 2, pp. 136-142. http://dx.doi.org/10.15171/PS.2017.20.

SÁNCHEZ-MACHADO, D.I., LÓPEZ-HERNÁNDEZ, J. and PASEIRO-LOSADA, P., 2002. High-performance liquid chromatographic determination of a-tocopherol in macroalgae. Journal of Chromatography. A, vol. 976, no. 1-2, pp. 277-284. http://dx.doi.org/10.1016/S0021-9673(02)00934-2. PMid:12462619.
SARHAN, M.A., SELIMA, K.A., KHALEL, K.I. and ROBYA, H.H., 2013. Evaluation of antioxidant activity, total phenols and phenolic compounds in thyme (Thymus vulgaris L.), sage (Salvia officinalis L.), and marjoram (Origanum majorana L.) extracts. Industrial Crops and Products, vol. 43, no. 1, pp. 827-831. http:// dx.doi.org/10.1016/j.indcrop.2012.08.029.

SAVCI, A., ALAN, Y., KOCPINAR, E.F., KURSAT, M., TOPDEMIR, S., KARATAS, M. and CAKMAK, B., 2019. The contents of phenolic matter and biological activities of Tanacetum kotschyi (Boiss.) Grierson and Tanacetum tomentellum (Boiss.) Grierson. Suleyman Demirel University. Journal of Science and Arts, vol. 14, pp. 112-126. http://dx.doi.org/10.29233/sdufeffd.457567.

SEILER, G.J., 1994. Oil concentration and fatty acid composition of a of north American Helianthus (Asteraceae) species. Economic Botany, vol. 48, no. 3, pp. 271-279. http://dx.doi.org/10.1007/ BF02862328.

SINGLETON, V.L., ORTHOFER, R. and LAMUELA-RAVENTOS, R.M., 1999. Analysis of total phenols and other oxidation substrates and antioxidants by means of Folin-Ciocalteu reagent. Methods in Enzymology, vol. 299, pp. 152-178. http://dx.doi.org/10.1016/ S0076-6879(99)99017-1.

SKOTTI, E., ANASTASAKI, E., KANELLOU, G., POLISSIOU, M. and TARANTILIS, P.A., 2014. Total phenolic content, antioxidant activity and toxicity of aqueous extracts from selected Greek medicinal and aromatic plants. Industrial Crops and Products, vol. 53, pp. 46-54. http://dx.doi.org/10.1016/j.indcrop.2013.12.013.

SPITALER, R., WINKLER, A., LINS, I., YANAR, S., STUPPNER, H. and ZIDORN, C., 2008. Altitudinal variation of phenolic contents in flowering heads of Arnica montana cv. ARBO: a 3-year comparison. Journal of Chemical Ecology, vol. 34, no. 3, pp. 369-375. http://dx.doi.org/10.1007/s10886-007-9407-x. PMid:18259818.

SYTAR, O., HEMMERICH, I., ZIVCAK, M., RAUH, C. and BRESTIC, M., 2018. Comparative analysis of bioactive phenolic compounds composition from 26 medicinal plants. Saudi Journal of Biological Sciences, vol. 25, no. 4, pp. 631-641. http://dx.doi. org/10.1016/j.sjbs.2016.01.036.

TEPE, B. and SOKMEN, A., 2007. Screening of the antioxidative properties and total phenolic contents of three endemic Tanacetum subspecies from Turkish flora. Bioresource Technology, vol. 98, no. 16, pp. 3076-3079. http://dx.doi.org/10.1016/j.biortech.2006.10.019. PMid: 17157500

TOSUN, Y.K., ERDEM, H., GENCE, C.C., 2018. The effect of nitrogen applications on grain sterol (campesterol, stigmasterol and betasitosterol) concentration of bread wheat varieties. Academic Journal of Agriculture, vol. 7, no. 2, pp. 185-190. http://dx.doi. org/10.29278/azd.476356.

TURHAN, H., CITAK, N., PEHLIVANOGLU, H. and MENGUL, Z., 2010. Effects of ecological and topographic conditions on oil content and fatty acid composition in sunflower. Bulgarian Journal of Agricultural Science, vol. 16, no. 5, pp. 553-558.

VARGA, L., ENGEL, R., SZABO, K., ABRANKÓ, L., GOSZTOLA, B., ZÁMBORINÉ NÉMETH, É. and SÁROSI, S., 2016. Seasonal variation in phenolic content and antioxidant activity of Glechoma Hederacea L. harvested from six Hungarian populations. Acta Alimentaria, vol. 45, no. 2, pp. 268-276. http:// dx.doi.org/10.1556/066.2016.45.2.14.

WOJDYLO, A., OSZMIANSKI, J. and CZEMERYS, R., 2007. Antioxidant activity and phenolic compounds in 32 selected 
herbs. Food Chemistry, vol. 105, no. 3, pp. 940-949. http://dx.doi. org/10.1016/j.foodchem.2007.04.038.

YUR, S., TEKIN, M., GOGER, F., BASER, K.H.C., OZEK, T. and OZEK, G., 2017. Composition and potential of Tanacetum haussknechtii Bornm. Grierson as antioxidant and inhibitor of acetylcholinesterase, tyrosinase, and $\alpha$-amylase enzymes. International Journal of Food Properties, vol. 20, suppl. 3, pp. S2359-S2378. http://dx.doi.org/10.1080/10942912.2017.1370600.

ZENGIN, G., SIENIAWSKA, E., SENKARDES, I., PICOT-ALLAIN, M.C.N., IBRAHIME SINAN, K. and FAWZI MAHOMOODALLY,
M., 2019. Antioxidant abilities, key enzyme inhibitory potential and phytochemical profile of Tanacetum poteriifolium Grierson. Industrial Crops and Products, vol. 140, pp. 111629. http://dx.doi. org/10.1016/j.indcrop.2019.111629.

ZU, Y., LI, C.Y., FU, Y.J. and ZHAO, C.J., 2006. Simultaneous determination of catechin, rutin, quercetin kaempferol and isorhamnetin in the extract of sea buckthorn (Hippophae rhamnoides L.) leaves by RP-HPLC with DAD. Journal of Pharmaceutical and Biomedical Analysis, vol. 41, no. 3, pp. 714-719. http://dx.doi. org/10.1016/j.jpba.2005.04.052. PMid:16520013. 